Research Report 1676

\title{
An Automated System for the Analysis of Combat Training Center Information: Strategy and Development
}

\author{
Dwight J. Goehring \\ U.S. Army Research Institute
}

\section{Unit Collective Training Research Unit Michael R. McCluskey, Acting Chief \\ Training Systems Research Division Jack H. Hiller, Director}

U.S. Army Research Institute for the Behavioral and Social Sciences 5001 Eisenhower Avenue, Alexandria, Virginia 22333-5600

Office, Deputy Chief of Staff for Personnel

Department of the Army

May 1995 